\title{
Nursing workload in an inpatient unit
}

Ana Paula de Brito ${ }^{1}$

Edinêis de Brito Guirardello²

This study evaluated the nursing workload in an inpatient unit of a university hospital. This descriptive study applied the Nursing Activities Score (NAS) over the course of 30 consecutive days. A total of 1,080 observations were obtained from the medical files of 156 patients. The average scored obtained in the NAS instrument was $47.31 \%$. Considering that each single NAS score corresponds to 0.24 hours, an average of 11.35 hours of nursing care was required. This amount of hours correspond to the profile of inpatients demanding semiintensive and intensive care, suggesting that the NAS can be used to evaluate the workload of the nursing staff in this unit.

Descriptors: Workload; Nursing Staff; Nursing Assessment; Nursing.

\footnotetext{
${ }^{1}$ RN, Master's Student in Nursing, Departamento de Enfermagem, Faculdade de Ciências Médicas, Universidade Estadual de Campinas, SP, Brazil. E-mail: anap@fcm.unicamp.br.

${ }^{2}$ RN, Free Lecture, Associate Professor, Departamento de Enfermagem, Faculdade de Ciências Médicas, Universidade Estadual de Campinas, SP, Brazil. E-mail: guirar@fcm.unicamp.br.
}

Corresponding Author:

Edinêis de Brito Guirardello

Universidade Estadual de Campinas. Faculdade de Ciências Médicas

Departamento de Enfermagem

Rua Tessália Vieira de Camargo, 126

Cidade Universitária "Zeferino Vaz"

Caixa Postal 6111, Campinas, SP, Brasil

E-mail: guirar@fcm.unicamp.br 


\section{Carga de trabalho de enfermagem em uma unidade de internação}

O objetivo deste estudo foi avaliar a carga de trabalho de enfermagem em uma unidade de internação de um hospital de ensino. Trata-se de estudo descritivo, com a aplicação do Nursing Activities Score (NAS), por 30 dias consecutivos. Foram 1.080 observações obtidas do registro de 156 pacientes, e a média do NAS foi de 47,31\%. Considerando que cada ponto do NAS corresponde a 0,24h, foram requeridas, em média, 11,35 horas de enfermagem na assistência em 24 horas, o que corresponde a um perfil de pacientes que requer cuidados semi-intensivos e intensivos, sugerindo que o NAS pode ser utilizado para avaliar a carga de trabalho de enfermagem nessa unidade.

Descritores: Carga de Trabalho; Recursos Humanos de Enfermagem; Avaliação em Enfermagem; Enfermagem.

\section{Carga de trabajo de la enfermería en una unidad de hospitalización}

Este estudio objetiva evaluar la carga de trabajo de enfermería en una unidad de internación de un hospital de enseñanza. Se trata de un estudio descriptivo con la aplicación del Nursing Activities Score (NAS), por 30 días consecutivos. Fueron 1080 observaciones obtenidas del registro de 156 pacientes y el promedio del NAS fue de $47,31 \%$. Considerando que cada punto del NAS corresponde a $0,24 \mathrm{~h}$, fueron requeridas, en promedio, 11,35 horas de enfermería en la asistencia en 24 horas, lo que corresponde a un perfil de pacientes que requiere cuidados semi-intensivos e intensivos, sugiriendo que el NAS puede ser utilizado para evaluar la carga de trabajo de enfermería en esa unidad.

Descriptores: Carga de Trabajo; Personal de Enfermería; Evaluación en Enfermería; Enfermería.

\section{Introduction}

The managerial dimension is an essential part within nurses' work process. The responsibilities of nurses in this dimension includes work organization and human resources in nursing, seeking to create and implement appropriate care conditions for patients and for the performance of workers ${ }^{(1)}$.

Nurses have some tools to be used in the management of human resources such as Patient Classification Systems (PCS) that enable them to evaluate the level of care complexity or the level of nursing workload required by patients. A PCS consists of the classification of patients into groups or categories of care actions and quantifying these categories as a measure of the demanded nursing effort ${ }^{(2)}$. It also enables one to determine, validate and monitor the care needs of patients, whose data can be used to support the apportioning of human resources, cost planning and quality of care $^{(3)}$.
There are, among all PCSs, instruments developed in Brazil for adult inpatients ${ }^{(4-8)}$, nursing residences ${ }^{(9)}$, pediatric patients(10) and instruments validated for the Brazilian culture such as the Nursing Activities Score $(N A S)^{(11)}$. We note that these instruments were developed to be used in hospitalization units, with the exception of the NAS, which was constructed to evaluate the workload of the nursing staff in Intensive Care Units (ICUs) $^{(12)}$.

When such tools are applied, they result in an indirect measure of nursing hours and often are not sensitive enough to identify the level of complexity of care required by patients. In a university hospital that provides tertiary and quaternary care, applying a tool to classify patients is difficult given the multiple medical specialties and the variability of complexity of care required by its patients. 
Even though the NAS was developed to evaluate the nursing workload in ICUs, its results are based on activities performed by the nursing staff, regardless of the characteristics of complexity presented by patients(12). Hence, it can be tested in hospitalization units, even if it requires studies to validate its efficiency from this perspective.

Since the studied facility does not have a semiintensive care unit, inpatients discharged from the ICU are allocated to hospitalization units. These patients, however, may require a heavy workload ${ }^{(13)}$, which in turn overloads the professionals in these sectors as they meet the care demands of these patients. This is a fact that requires greater investigation because imbalance in the proportion between patients and nurses has important implications for the safety of patients, for hospital mortality and morbidity, professionals turnover, and for different aspects related to the health of workers such as the occurrence of burnout syndrome and professional dissatisfaction ${ }^{(14)}$.

Given the preceding discussion, the primary objective of this study is to measure the workload required by patients cared for in a hospitalization unit of a university hospital and, secondly, to evaluate the variables of workload and how the frequency of nursing activities differs between the unit's subunits.

\section{Method}

This descriptive study was carried out in an inpatient unit of a university hospital that provides tertiary and quaternary care. The unit has 36 beds divided into two subunits and cares for patients from different medical specialties. Subunit 1 (S1) contains 18 medical clinic beds and Subunit 3 (S3) contains four medical clinic beds, nine for vascular surgery, four for dermatology, and one for endocrinology.

Inpatients from both subunits were included in the sample, provided they were 18 years old or older and hospitalized for 24 hours or more, regardless of the medical diagnosis or type of treatment. We consider the reason the patient was hospitalized to describe the medical diagnoses. The reasons were later classified according to the International Classification of Diseases $^{(15)}$.

The NAS instrument, developed by Miranda et al.(12) and validated for the Brazilian culture was used for collecting data(11). It measures nursing workload in ICUs and is composed of 23 care interventions, divided into seven large categories: basic activities (monitoring, medication, hygiene procedures, administrative tasks, among others), ventilatory, cardiovascular, renal, neurological, and metabolic support and specific interventions.

Each intervention is scored according to a percentage and the sum of such scores reflects the time the nursing staff spent caring for a patient in a 24 hours period. Scores may range from zero to $177 \%$, that is, cases in which this figure pass $100 \%$ require more than a nursing professional to care for the patient on a given day $^{(12)}$. To characterize patient profiles, we used a form containing their demographic and clinical data.

A pretest was performed prior to data collection so we would become familiar with the instrument. Data were collected for 30 consecutive days, always at the same time through the verification and evaluation of nursing records and consulting the patients' medical files to obtain clinical and demographic data. Beds were considered when applying NAS because the same bed may be used by various patients over a period of hospitalization. Aiming to standardize the meaning of each of the NAS items and to avoid potential interpretation errors, the recommended guidelines were used to apply the instrument ${ }^{(16)}$.

The project was approved by the Ethics Research Committee (Protocol no 322/2009), which did not require consent forms to be signed since evaluating the patients' care demands is considered to be part of a nurse's routine activity and patients did not undergo any additional procedure with the instrument's application.

Data were stored in an electronic spreadsheet in Microsoft ${ }^{\circledR}$ Excel and analyzed using SPSS ${ }^{\circledR} 16.0$ for Windows. Tables present the frequency of the categorical variables and descriptive statistics (average, standard deviation, median, minimum and maximum) of the continuous variables.

The Chi-square test was used to verify potential associations between the subunits in relation to the categorical variables and Fisher's exact test was used when the expected values were below five. The MannWhitney non-parametric test was applied to compare the stations in relation to continuous variables. The level of significance was fixed at $5 \%$, that is, the p-value $\leq$ 0.05 .

\section{Results}

The sample was composed of 156 patients and their clinical and demographic characteristics are presented in Table 1. 
When verifying whether there was a statistical $(p=0.048)$, who had undergone surgical treatments difference in the profile of patients between the subunits, we observed that subunit 3 had a predominance of male patients $(p=0.016)$, older than 60 years of age $(p=0.001)$, with diseases in the circulatory system, and originated from the hospitalization unit $(p=0.001)$ in relation to subunit 1 (Table 1 ).

Table 1 - Demographic and clinical data of patients in the hospitalization unit and in its stations. Campinas, SP, Brazil, 2009

\begin{tabular}{|c|c|c|c|c|}
\hline \multirow{2}{*}{ Variables } & \multirow{2}{*}{$\begin{array}{c}\text { Hospitalization Unit } \\
\mathbf{n}(\%)\end{array}$} & \multirow{2}{*}{$\begin{array}{c}\text { Subunit } 1 \\
\mathrm{n}(\%)\end{array}$} & \multirow{2}{*}{$\begin{array}{c}\text { Subunit } 3 \\
\mathrm{n}(\%)\end{array}$} & \multirow{2}{*}{ p-value } \\
\hline & & & & \\
\hline Gender & & & & $0.016^{*}$ \\
\hline Male & $94(60.3)$ & $29(48.3)$ & $65(67.7)$ & \\
\hline Female & $62(39.7)$ & $31(51.7)$ & $31(32.3)$ & \\
\hline Age & & & & $0.048^{*}$ \\
\hline$<30$ & $20(12.8)$ & $10(16.6)$ & $10(10.4)$ & \\
\hline $31-40$ & $18(11.5)$ & $10(16.6)$ & $8(8.3)$ & \\
\hline $41-50$ & $12(7.7)$ & $5(8.3)$ & $7(7.2)$ & \\
\hline $51-60$ & $33(21.1)$ & $16(26.6)$ & $17(17.7)$ & \\
\hline$>60$ & $73(46.8)$ & $19(31.6)$ & $54(56.2)$ & \\
\hline Origin & & & & $<0.001^{\dagger}$ \\
\hline Hospitalization & 52 & $3(5.0)$ & $49(51.0)$ & \\
\hline Referenced Emergency Department & 50 & $34(57.0)$ & $16(17.0)$ & \\
\hline Nursing wards & 20 & $9(15.0)$ & $11(11.0)$ & \\
\hline Outpatient clinics & 14 & $11(18.0)$ & $3(3.0)$ & \\
\hline Surgical Center & 10 & 0 & $6(6.0)$ & \\
\hline ICUs & 8 & $2(3.0)$ & $10(10.0)$ & \\
\hline Other hospitals & 2 & $1(2.0)$ & $1(1.0)$ & \\
\hline Treatment & & & & $<0.001^{*}$ \\
\hline Clinical & $82(52.5)$ & $57(95.0)$ & $25(26.0)$ & \\
\hline Surgical & $74(47.5)$ & $3(5.0)$ & $71(74.0)$ & \\
\hline Time of hospitalization & & & & $<0.001^{\dagger}$ \\
\hline Average & 10.3 & 12.5 & 8.14 & \\
\hline Minimum & 1 & 4 & 1 & \\
\hline Maximum & 39 & 39 & 25 & \\
\hline Main Diagnoses ${ }^{\ddagger}$ & & & & $<0.001^{\dagger}$ \\
\hline Circulatory system diseases & $71(45.5)$ & $13(21.7)$ & $58(61.7)$ & \\
\hline Respiratory tract diseases & $16(10.3)$ & $12(20.0)$ & $4(4.3)$ & \\
\hline Neoplasias & $11(7.1)$ & $3(5.0)$ & $8(8.5)$ & \\
\hline Endocrine diseases & $10(6.4)$ & $6(10.0)$ & $4(4.3)$ & \\
\hline Skin and subcutaneous tissue disorders & $9(5.8)$ & $5(8.3)$ & $4(4.3)$ & \\
\hline
\end{tabular}

${ }^{*}$ Chi-square test ${ }^{+}$Fisher's exact test; ${ }^{\ddagger}$ According to the International Classification of Diseases (ICD X)

The NAS was applied over 30 consecutive days in both subunits of the hospitalization unit, totaling 1,080 observations obtained from the medical files of 156 patients. The number of observations does not correspond to the total number of patients; the same patient may have been classified more than once depending on his/her stay in the studied unit.

The average score obtained in the NAS, considering the unit and its respective subunits, is presented in Table 2. The minimum score (zero) means the bed was empty for one day during data collection.

Table 2 - Description of the average score, median, and standard deviation of workload according to the NAS in the hospitalization unit. Campinas, SP, Brazil, 2009

\begin{tabular}{|c|c|c|c|c|c|c|}
\hline Hospitalization unit & $\mathbf{n}$ & Average & SD & Median & Minimum & Maximum \\
\hline Subunit 1 & 540 & 44.2 & 5.3 & 44.2 & 0 & 153.2 \\
\hline Subunit 3 & 540 & 50.5 & 6.1 & 50.3 & 0 & 157.4 \\
\hline Total & 1,080 & 47.3 & 5.2 & 48.8 & 0 & 157.4 \\
\hline
\end{tabular}


When evaluating the percentage of workload per bed we verified that the highest averages were obtained by patients hospitalized in rooms assigned based on allocating individuals who demand care with a greater level of complexity, such as beds close to the nursing ward, which allows the team to maintain constant surveillance. Similarly, beds with an energy generation system also obtained higher averages in NAS because these are designed for patients requiring technologically sophisticated equipment, such as mechanical ventilators, multi-parameter monitors and infusion pumps. No statistical significance was observed between the two subunits in relation to these beds $(p=0.217)$.
Considering that the NAS permits one to evaluate nursing activities performed over the course of 24 hours of care, we could evaluate the frequency with which NAS items and sub-items appear (Table 3). The most frequent items and sub-items were: 1a) Vital signs schedules, regular recording of water balance; 3) medication, except vasoactive drugs; 7a) Support and care to family members and patients who demand exclusive dedication for about one hour during any of the shifts; 8a) routine tasks such as: clinical data processing, ordering exams, exchange of professional information, and 17) quantitative measurement of urine output. These appeared with a frequency above $70 \%$ and no statistical differences were found between the two subunits for these items $(p=0.615)$.

Table 3 - Description of the most frequent NAS items and sub-items in the hospitalization unit per subunit. Campinas, SP, Brazil, 2009

\begin{tabular}{|c|c|c|c|c|c|c|}
\hline \multirow{2}{*}{ Items } & \multirow{2}{*}{ Nursing Activities Score } & \multicolumn{2}{|c|}{ Subunit 1} & \multicolumn{2}{|c|}{ Subunit 3} & \multirow{2}{*}{ p-value* } \\
\hline & & $\mathbf{n}$ & f & $\mathbf{n}$ & $\mathbf{f}$ & \\
\hline $1 \mathrm{a}$ & Vital signs schedules, calculation, and regular recording of water balance & 399 & 50 & 398 & 50 & 0.615 \\
\hline 3 & Medication, except vasoactive drugs & 492 & 49 & 512 & 51 & \\
\hline $7 a$ & $\begin{array}{l}\text { Support and care provided to family members and patients who required } \\
\text { exclusive dedication for about one hour during any shift }\end{array}$ & 447 & 50 & 447 & 50 & \\
\hline $8 a$ & $\begin{array}{l}\text { Routine tasks such as: clinical data processing, ordering exams, } \\
\text { exchange of professional information }\end{array}$ & 451 & 48.2 & 485 & 51.8 & \\
\hline 17 & Quantitative measurement of urine output & 356 & 46.6 & 408 & 53.4 & \\
\hline
\end{tabular}

*Chi-square test

\section{Discussion}

The study's results indicate a predominance of male patients with an average age of 54.9 years old. Most underwent clinical treatment with their main medical diagnosis related to the circulatory system. There was an average duration of hospitalization of 10.32 days. Subunit 3 presented a higher hospitalization turnover because it receives patients undergoing procedures that require short hospitalization periods, such as patients from dermatology, endocrinology and ophthalmology.

The most frequent diagnoses are related to diseases in the circulatory and respiratory systems and neoplasias. Considering that $50 \%$ of the patients cared for at the unit are older than 60 years of age, these are the diseases expected in this unit(17). Given population aging, a predominance of chronic diseases and related forms of impairment is observed. It is worth noting that this pattern of diseases demands constant health care and high costs accruing from continuous medication, periodic exams, and longer hospitalizations ${ }^{(18)}$.
A predominance of male and elderly patients was observed in subunit 3 in relation to subunit 1 . Most patients were diagnosed with circulatory system diseases that mainly affect men ${ }^{(19)}$; chronic-degenerative diseases were observed in this subunit, a situation that has increased in the current elderly population.

There is a predominance of patients undergoing clinical treatment in subunit 1 , which may be justified by the unit's organization, whose beds are reserved for patients from the specialty of internal medicine, which includes diagnostic investigations. Hence, treatment in this unit is focused on exams and other procedures without the need for surgical intervention, at least not initially. On the other hand, patients with surgical treatment predominate in subunit 3, since vascular surgery accounts for half of the subunit's beds and in $98 \%$ of the cases has surgical procedures as well as otolaryngology and dermatology.

The nursing workload indicated by the NAS was $47.3 \%$. Even though we do not have studies available to compare workloads with this profile of patients, this workload was greater than that verified in a study 
conducted in a gastroenterology unit(20) and less than that found in a study addressing individuals hospitalized in a high-dependency unit(21). The workload found in this study is also less than that found in other studies carried out in ICUs, which is expected since patients in these

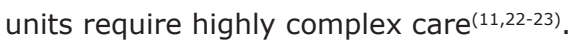

These differences in the percentage of workload may be related to the profile of each group of patients and to the units' characteristics, such as the physical and organizational structure, factors that influence the nursing workload and, consequently, time spent with care. Another aspect involves the interpretation of the NAS manual concerning its implementation, which needs to be appropriate given the factors previously mentioned, even if there is a certain level of subjectivity in the instruments' application, inherent to any evaluation of nursing care $^{(2)}$.

Even though statistically significant differences were not observed between the subunits, subunit 3 scored higher on the NAS than subunit 1 . One of the explanations is that subunit 3 mainly receives elderly patients with vascular problems who undergo limb amputation ${ }^{(19,24)}$. Hence, they require more intensive nursing care concerning mobility, dressings, bandages and pain relief.

The most frequent activities were those related to the administration of medication, guidance provided to patients and family members, monitoring of patients, control of diuresis and administrative activities. It is interesting to note that the administrative activities and support and assistance provided to family members and patients are related to nursing activities not addressed in other instruments designed to evaluate the complexity of care delivered to patients, which indicates the relevance of using the NAS in such an evaluation.

These results are evidence for the viability of applying the NAS in the studied unit, showing that patients hospitalized in clinical-surgical units require nursing care that is represented by the activities that compose the NAS, even though there is some variation in the frequency of these activities and others are not identified, as expected, because these are specific to environments of critical care.

The previous discussion leads to the conclusion that the activities addressed by the NAS can be evaluated in other profiles of patients because they are based on nursing activities, regardless of the level of complexity presented by patients, as stressed by the instrument's author $^{(12)}$.
The score obtained in the NAS was converted into hours in order to compare the workload that resulted from its application with that recommended by the Brazilian Federal Council of Nursing's (COFEN) resolution(25). Considering that each score in the NAS corresponds to 0.24 hours $^{(12)}$, an average of 11.35 hours of nursing care was required in the course of 24 hours, which corresponds to a profile of patients who demand semi-intensive and intensive care. Such a workload is greater than that recommended by COFEN but still used in the unit to allocate human resources.

\section{Conclusions}

This study allowed us to evaluate the applicability of NAS in a hospitalization unit. The nursing workload in the unit was $47.31 \%$ and it varied when comparisons among the subunits were made. The most frequent items and sub-items are those related to basic nursing activities, which is expected for this profile of patients.

A predominance of elderly and male individuals affected by chronic-degenerative diseases was observed. The comparison between the score obtained by unit on the NAS and the nursing hours recommended by COFEN indicates it corresponds to the profile of patients who require semi-intensive and intensive care.

Even though the NAS is an instrument whose applicability is recommended for ICUs, its usefulness as a tool to determine the nursing workload in the studied, non-ICU, unit was demonstrated. Further studies capable to relate nursing workload with other clinical indicators are required.

\section{References}

1. Felli VEAF, Peduzzi M. O trabalho gerencial em enfermagem. In: Kurcgant P. Gerenciamento em enfermagem. São Paulo (SP): Guanabara Koogan; 2005. p. 1-13.

2. Giovannetti P. Understanding patient classification systems. J Nurs Adm. 1979;9(2):4-9.

3. De Groot HA. Patient classification system evaluation Part 1: essential system elements. J Nurs Adm. $1989 ; 19(6): 30-5$.

4. Fugulin FMT, Silva SHS, Shimizu HE, Campos FPF. Implantação do sistema de classificação de pacientes na unidade de clínica médica do hospital universitário da USP. Rev Med HU-USP. 1994;4(1/2):63-8.

5. Fugulin FMT, Gaidzinski RR, Kurcgant P. Sistema 
de classificação de pacientes: identificação do perfil assistencial dos pacientes das unidades de internação do HU-USP. Rev. Latino-Am. Enfermagem. 2005;13(1):72-8.

6. Santos F, Rogenski NMB, Baptista CMC, Fugulin FMT. Patient classification system: a proposal to complement the instrument by Fugulin et al. Rev. Latino-Am. Enfermagem. 2007;15(5):980-5.

7. Perroca MG, Gaidzinski RR. Sistema de classificação de pacientes: construção e validação de um instrumento. Rev Esc Enferm USP. 1998;32(2):153-68.

8. Martins EAP, Haddad MCL. Validação de um instrumento que classifica os pacientes em quatro graus de dependência do cuidado de enfermagem. Rev. LatinoAm. Enfermagem. 2000;8(2):74-82.

9. Dal Ben LW, Sousa RMC. Instrumento para dimensionar horas diárias de assistência de enfermagem residencial. Rev Esc Enferm USP. 2004;38(1):80-9.

10. Dini AP. Sistema de classificação de pacientes pediátricos: construção e validação de instrumento [dissertação]. Campinas (SP): Universidade Estadual de Campinas; 2007. 170 p.

11. Queijo AF, Padilha KG. Nursing Activities Score (NAS): adaptação transcultural e validação para a língua portuguesa. Rev Esc Enferm USP. 2009;43(Esp):1018-25. 12. Miranda DR, Nap R, Rijk A, Schaufeli W, Iapichino G. Nursing Activities Score. Crit Care Med. 2003;31(2):374-82

13. Silva MCM, Sousa RMC, Padilha KG. Patient estination after discharge from intensive care units: wards or intermediate care units? Rev. Latino-Am. Enfermagem. 2010;18(2):224-32.

14. Aiken LH, Clarke SP, Sloane DM, Sochalski J, Silber $\mathrm{JH}$. Hospital nurse staffing and patient mortality, nurse burnout, and job dissatisfaction. JAMA. 2002;288(16):1987-93.

15. Departamento de informática do SUS (BR). [internet]. Classificação Internacional de Doenças [acesso 29 jun 2009]. Disponível em: http://www.datasus.gov.br/ cid10/v2008/cid10.htm.

16. Gonçalves LA, Padilha KG. Nursing Activities Score (NAS) Proposta de aplicação prática em unidade de terapia intensiva. Prática Hosp. 2005;7(42). [acesso 12 mai 2009]. Disponível em: http://www.praticahospitalar. com.br/pratica\%2042/pgs/materia\%2033-42.html 17. Simões CCS. Perfis de saúde e de mortalidade no Brasil: uma análise de seus condicionantes em grupos populacionais específicos. Brasília (DF): Organização Pan-Americana de Saúde; 2002. 141 p.

18. Veras R. Envelhecimento populacional contemporâneo: demandas, desafios e inovações. Rev Saúde Pública. 2009;43(3):548-54.

19. Menezes FH, Luccas GC, Lane JC. Manual de moléstias vasculares. Rio de Janeiro: AC Farmacêutica; 2009. 168 p.

20. Panunto MR, Guirardello EB. Nursing workload at a gastroenterology unit. Rev. Latino-Am. Enfermagem. 2009;17(6):1009-14.

21. Lima MKF, Tsukamoto R, Fugulin MFT. Aplicação do Nursing Activities Score em pacientes de alta dependência de enfermagem. Texto Contexto Enferm. 2008;17(4):638-46.

22. Conishi RMY, Gaidizinski RR. Nursing Activities Score (NAS) como instrumento para medir carga de trabalho de enfermagem em UTI adulto. Rev Esc Enferm USP. 2007;41(3):346-54.

23. Gonçalves LA, Padilha KG. Fatores associados à carga de trabalho de enfermagem em uma unidade de terapia intensiva de adultos no primeiro dia de internação. Rev Esc Enferm USP. 2007;41(4):645-52.

24. Agne JE, Cassol CM, Bataglion D, Ferreira FV. Identificação das causas de amputação de membros no hospital universitário de Santa Maria. Saúde. 2004;30(12):84-9.

25. Resolução 293, de 21 de setembro de 2004 (COFEN) (BR). Fixa e estabelece parâmetros para o dimensionamento de pessoal de enfermagem nas unidades assistenciais das instituições de saúde e assemelhados. 2004 [acesso 12 mai 2009]. Disponível em: http://www.portalcofen.com.br/2007/materias.asp ?ArticleID=7121\&sectionID $=34$. 